\title{
Experimental ulcerative herpetic keratitis. III. Evaluation of hyperimmune gammaglobulin therapy
}

\author{
C. A. CARTER ${ }^{1}$ AND D. L. EASTY ${ }^{2}$ \\ From the ${ }^{1}$ Department of Surgery, Medical School, University of Bristol; and \\ ${ }^{2}$ Bristol Eye Hospital, Lower Maudlin Street, Bristol
}

SUMMARY The value of hyperimmune gammaglobulin (HGG) therapy in ulcerative herpetic keratitis was assessed in rabbits. HGG treatment of early disease in normal rabbits was very effective, producing a 10 -fold rise in the virus concentration needed to infect $50 \%$ of sites $\left(\mathrm{CID}_{50}\right)$ and an $88 \%$ inhibition of ulceration after 2 days. The efficacy of the gammaglobulin preparations tested depended on their anti-HSV antibody content. Established disease was considerably less responsive to HGG therapy. No conclusive effect of HGG therapy could be demonstrated in rabbits with a previous HSV skin infection ('immunised'). Corticosteroid-induced geographic ulceration in immunised rabbits was not prevented by concurrent HGG therapy. The findings indicate that HGG is unlikely to represent a useful therapy for ulcerative herpetic keratitis but that it may be valuable in primary disease and in long-term prophylaxis.

The pathogenesis of ulcerative herpetic keratitis is due to active proliferation of herpes simplex virus (HSV) in exposed ulcers of the corneal epithelium, where virus particles and infected cells may be relatively accessible to topically administered anti-HSV antibody. Free particles in the tear film could also be neutralised by antibody, preventing reinfection. Human gammaglobulin has been used in the treatment of herpetic keratitis, ${ }^{1-3}$ but to our knowledge no controlled experimental studies of the value of gammaglobulin in ulcerative herpetic keratitis have been reported.

Normal human gammaglobulin contains a proportion of anti-HSV antibodies, but a higher antibody titre is found in specific hyperimmune gammaglobulin (HGG). In this study we have used an animal model to study the effects of HGG in ulcerative herpetic keratitis. We compared the effects of HGG treatment on early and established disease in normal rabbits, early infection of immunised rabbits, ${ }^{4}$ and steroidenhanced disease in immunised animals. ${ }^{5}$

Correspondence to Miss C. A. Carter, Bristol Eye Hospital, Lower Maudlin Street, Bristol BS1 2LX.

\section{Material and methods}

Three types of gammaglobulin were used, produced by routine processes ${ }^{6}$ from donated human blood. Negative was prepared from sera containing no neutralising antibody to HSV; normal (available commercially) was prepared from unselected sera; and immune (HGG) was prepared from sera of individuals with recent HSV infections. The $50 \%$ neutralising antibody titres were $1 / 1280$ for normal gammaglobulin and $1 / 2400$ for HGG. Negative gammaglobulin or artificial tears (Hypromellose) were used as placebo. Topical treatment comprised 5 drops daily, at $1 \frac{1}{2}$ hour intervals. In all experiments gammaglobulin was administered to one eye of each rabbit and placebo to the other, and the allocation of treatment was unknown to the observer. The details of the virus and animals used and the methods of immunisation of rabbits, corneal inoculation of virus, and assessment of corneal disease have been described. ${ }^{4}$ The ranges of virus concentration used were 0.4 to $26 \cdot 1 \times 10^{5} \mathrm{PFU} / \mathrm{ml}$ or 0.02 to $15.6 \times 10^{5} \mathrm{PFU} / \mathrm{ml}$ for normal and 3.9 to $250.0 \times 10^{5} \mathrm{PFU} / \mathrm{ml}$ for immunised rabbits $(\mathrm{PFU}=$ plaque-forming units).

In normal animals treatment of early disease 
began on day $0,1 \frac{1}{2}$ hours after corneal inoculation of virus. Negative, normal, and immune gammaglobulins were tested in experiments involving 5,3 , and 4 rabbits respectively. Treatment of established disease began on day 2 , in a total of 9 rabbits. Treatment of immunised rabbits began on day 0 (4 animals). Corticosteroid-induced geographic ulceration was induced in immunised animals according to the model developed previously. ${ }^{5}$ Five immunised rabbits were treated with $0.1 \%$ clobetasone butyrate from day -1 , and HGG or placebo treatment was initiated on day 0 .

\section{Results}

EARLY DISEASE IN NORMAL ANIMALS HGG treatment was very effective, producing a large rise in corneal infectious dose for $50 \%$ of inoculations $\left(\mathrm{CID}_{50}\right)$ when compared with Hypromellose or negative gammaglobulin. Normal gammaglobulin had a smaller effect, while negative gammaglobulin was no different from placebo. The areas of corneal ulceration observed on days 2 and 4 also showed that negative gammaglobulin had no significant effect, while normal gammaglobulin had some effect and HGG a considerable inhibitory effect on ulceration ( $<<0.02$ by the Wilcoxon rank sum test) (Table 1).

ES T A B L IS HED D IS EASE IN

N O R M A L A N.MA L S

On day 4, after 2 days' treatment, the difference in areas of ulceration between HGG- and

Table 1 Mean $C I D_{50}$ and percentage inhibition of ulceration values on day 2 , after beginning of treatment on day 0.

\begin{tabular}{|c|c|c|c|c|c|}
\hline \multirow[t]{2}{*}{ Rabbits } & \multicolumn{2}{|l|}{ Treatment } & \multicolumn{2}{|l|}{$C I D_{50}$} & \multirow{2}{*}{$\begin{array}{l}\% \text { Inhibition } \\
\text { of ulceration } \\
\text { day } 2\end{array}$} \\
\hline & Control & $\begin{array}{l}\text { Experi- } \\
\text { mental }\end{array}$ & Control & $\begin{array}{l}\text { Experi- } \\
\text { mental }\end{array}$ & \\
\hline Normal & $\begin{array}{l}\text { Negative } \\
\text { gamma- } \\
\text { globulin }\end{array}$ & HGG & $3 \cdot 4$ & $35 \cdot 1$ & $87 \cdot 6$ \\
\hline Normal & $\begin{array}{l}\text { Hypro- } \\
\text { mellose }\end{array}$ & $\begin{array}{l}\text { Negative } \\
\text { gamma- } \\
\text { globulin }\end{array}$ & $3 \cdot 5$ & $3 \cdot 1$ & $6 \cdot 6$ \\
\hline Normal & $\begin{array}{l}\text { Hypro- } \\
\text { mellose }\end{array}$ & $\begin{array}{l}\text { Normal } \\
\text { gamma- } \\
\text { globulin }\end{array}$ & $5 \cdot 2$ & $29 \cdot 2$ & $65 \cdot 3$ \\
\hline $\begin{array}{l}\text { Normal } \\
\text { Immunised }\end{array}$ & $\begin{array}{l}\text { Hypro- } \\
\text { mellose } \\
\text { Negative }\end{array}$ & HGG & $1 \cdot 5$ & $62 \cdot 5$ & $92 \cdot 3$ \\
\hline & $\begin{array}{l}\text { gamma- } \\
\text { globulin }\end{array}$ & HGG & $135 \cdot 6$ & $192 \cdot 8$ & -15.6 \\
\hline Immunised & $\begin{array}{l}\text { Steroid } \\
\text { Hypro- } \\
\text { mellose }\end{array}$ & $\begin{array}{l}\text { Steroid } \\
+ \\
\text { HGG }\end{array}$ & $143 \cdot 0$ & $205 \cdot 1$ & $13 \cdot 1$ \\
\hline
\end{tabular}

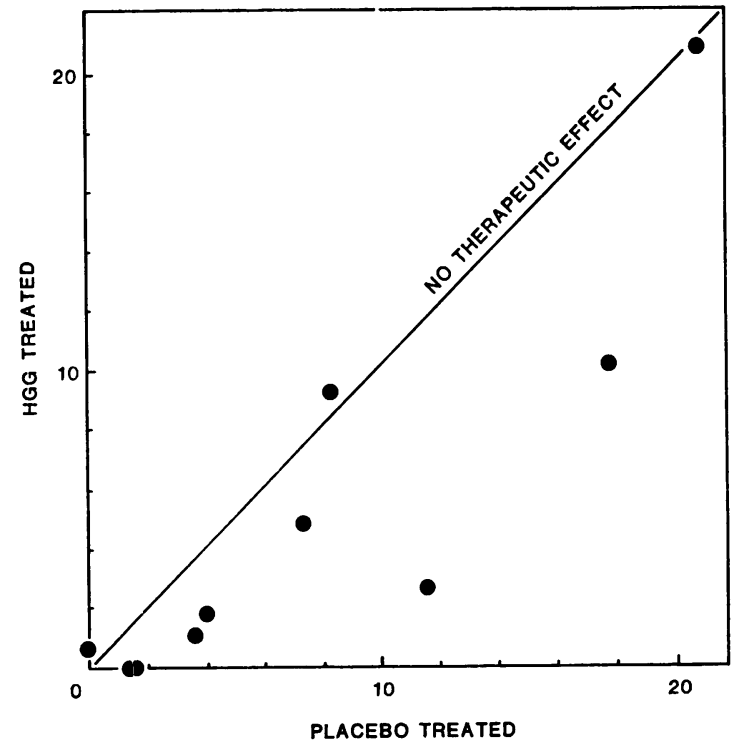

Fig. 1 Comparison of HGG and placebo treatment of established disease; areas of ulceration (\% of cornea) on day 4.

placebo-treated eyes was very much less marked than in rabbits treated from day 0 . A reduced area of ulceration in HGG-treated eyes was observed in 8 of 10 rabbits ( $<<0.05$ by the Wilcoxon signed rank test), and this effect appeared to be greater where the initial extent of ulceration was small (Fig. 1).

\section{EARL Y D IS EASE I N I M MUN IS ED}

\section{A N I M A L S}

No significant effect of HGG was found in immunised animals. No increase in the $\mathrm{CID}_{50}$ value was produced by HGG treatment, and no differences were found between areas of ulceration in HGG- and placebo-treated eyes on day 2, although on day 4,2 of 4 rabbits showed a reduction in area of ulceration (Table 1).

CORTICOSTEROID - I N D U C ED

D I S E A S E I N I M M U N IS D D A I MA L S

No effect of HGG was found, even at the time of maximum corticosteroid-induced increase in ulceration, 7 days after the inoculation of virus and commencement of HGG treatment (Table 1, Fig. 2).

\section{Discussion}

These findings show that topical HGG therapy is effective in a rabbit model of ulcerative herpetic keratitis when administered to normal 


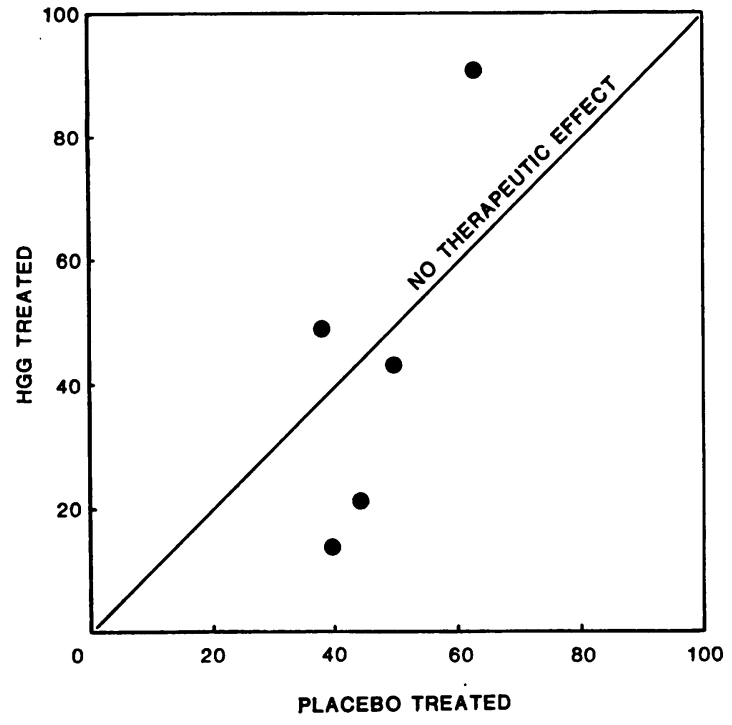

Fig. 2 Comparison of HGG and placebo treatment in corticosteroid-enhanced disease in immunised animals; areas of ulceration $(\%$ of cornea) on day 7 .

animals at an early stage in the disease process and that this effect is related to the anti-HSV antibody content of the preparation. However, if treatment is delayed until the infection has become established, it has a greatly reduced efficacy, which does not compare favourably with that of established antiviral substances in this model. ${ }^{7}$ HGG has no significant effect on disease in immunised rabbits, nor does it inhibit the enhancement of ulceration which results from corticosteroid treatment in immunised animals. These findings suggest that HGG therapy would have little value in the majority of clinical cases of ulcerative herpetic keratitis which present as established disease in patients with immune responses to the virus. The lack of effect in steroid enhanced ulceration indicates that HGG cannot be used as 'cover' for corticosteroid treatment. Although it has been reported that topical human gammaglobulin can be useful in the treatment of ulcerative and stromal herpetic keratitis, ${ }^{23}$ the preparation has not become generally accepted as a worthwhile therapy.

The considerable efficacy of HGG administered early in infection in normal rabbits shows that it could be a valuable nontoxic prophylactic agent, especially when immune responses are absent or deficient. Corneal infection following primary herpes simplex blepharoconjunctivitis, and the severe herpetic keratitis to which immunodeficient and immunosuppressed patients are liable, ${ }^{8}$ might be prevented by the topical administration of HGG.

Although anti-HSV antibody has been shown to have significant inhibitory effects on HSV infections in vitro, ${ }^{9-12}$ the influence of antibody is presumably limited by its inability to reach replicating virus inside cells. The disruption of infected cells to expose these virus particles is the basis for the use of cryosurgery prior to antibody treatment. ${ }^{1}$ However, the dangers of cryosurgery restrict the applications of this method. An alternative approach to the problem of intracellular infection is that of Zirm (personal communication, 1980) whereby Fab fragments of the antibody molecule, which can penetrate cells, are used. Such preparations may have considerable potential, especially if derived from a gammaglobulin material with a high antibody titre. (Note added in proof: This material was subsequently tested in this model but was not found to influence established disease in normal rabbits.)

It may be concluded that, although HGG has the advantage of low toxicity and low cost, the limitations to its efficacy shown in the present study indicate that it is unlikely to be a useful therapeutic agent. However, it may be valuable in primary disease and as a long-term prophylactic in immunosuppressed patients.

We greatly appreciate the help of Drs W. d'A Maycock, R. S. Lane, C. R. Rackham, and E. D. Wesley of the Blood Products Laboratory, Elstree, Herts, in generously providing the gammaglobulin preparations. We are grateful for the help and encouragement of Professor J. H. Peacock and Dr M. O. Symes and the practical assistance of Mr P. W. Madden. This work was kindly supported by a Research to Prevent Blindness grant from the RNIB.

\section{References}

1 Amoils SP, Maier G. Cryosurgery and immunotherapy in herpes keratitis. Br J Ophthalmol 1973; 57:809-14.

2 Bonamour, Dugarre. (1959) Local gamma globulin in ocular therapeutics. Bull Soc Ophthalmol Fr 1959; 5-6:438-41.

3 Cuccagna F, Damiani A. First results on the treatment of herpetic keratitis with gamma globulins. G Ital Oftalmol 1956; 9:671-83.

4 Carter CA, Easty DL. Experimental ulcerative herpetic keratitis. I. Systemic immune responses and resistance to corneal infection. $\mathrm{Br} J$ Ophthalmol 1981; 65:77-81.

5 Carter CA, Easty DL, Walker SR. Experimental ulcerative herpetic keratitis. II. Influence of topical corticosteroid in immunised rabbits. $\mathrm{Br} \mathrm{J}$ Ophthalmol. In press.

6 Kistler P, Nitschman H. Large scale production of human plasma fractions. Vox Sang 1962; 7:414-24.

7 Markham RHC, Carter C, Scobie M, Metcalf C, Easty DL. Double blind clinical trial of adenine arabinoside and idoxuridine in herpetic corneal ulcers. Trans Ophthalmol Soc UK 1977; 97:333-40.

8 Easty DL. Manifestations of immunodeficiency diseases 
in ophthalmology. Trans Ophthalmol Soc UK 1977; 97:8-17.

9 McClung H, Seth P, Rawls WE. Quantitation of antibodies to HSV-1 and -2 by complement-dependent antibody lysis of infected cells. Am J Epidemiol 1976; 104:181-91.

10 Oleske JM, Ashman B, Kohl S, et al. Human polymorphonuclear leucocytes as mediators of antibody- dependent cell cytotoxicity to HSV-infected cells. Clin Exp Immunol 1977; 27:446-53.

11 Skinner GRB, Mushi EZ, Whitney JE. Immune inhibition of virus release from herpes simplex virusinfected cells. Intervirology 1975/6; 6:296-308.

12 Pavan PR, Ennis FA. The elimination of herpes simplex plaques by antibody and the emergency of resistant strains. J Immunol 1977; 118:2167-75. 